\title{
Pesticides Characters, Importance and Microbial Degradation
}

\author{
Magda M. Aly ${ }^{1.2^{*}}$, Buthinah A. Al-aidaroos ${ }^{1}$ and Fahad A. Alfassi ${ }^{1}$ \\ 1 Biology Department, Faculty of Science, King Abdulaziz University, Saudi Arabia 2Botany Department, \\ Faculty of Science, Kafr el-Sheikh University, Egypt
}

\begin{abstract}
Agriculture in Saudi Arabia has been growing rapidly over the years and date palm (Phoenix dactylifera) is the most important agricultural crop.The red palm weevil, Rhynchophorus ferrugineus or Oliver, is considered one of the most economically important pest that attack date palm and many others crops, thus farmers usually use a variety of different types of chemicals called pesticide that are widely used for pest control worldwide, especially in the developing countries. Their residues result in serious problems not only in the cultivated soils where they are applied, but also in the crops that systemically retain part of these residues, in non-target organisms, and finally in the surface and underground water. However, due to its high persistence and illegal applications, residues still contaminate some environments that serve as the last destination for agricultural drainage. Certain microorganisms can survive in this contaminated place and have a potential as pesticide degrading microorganisms' through different mechanisms.
\end{abstract}

Keywords: Diazinon, degradation, bacteria, pesticide, date palm, Rhynchophorus

\section{Introduction}

Kingdom of Saudi Arabia is one of the major producers of fine quality dates and has 23 million trees of date palm which were under threat due to highly invasive red palm weevil and different pesticide can be used to control this insect. Chemical control of red palm weevil using pesticideis still practiced as one of the preferred method throughout the Gulf region and other parts of the world. Commercial formulations of systemic and non-systemic pesticides are being used indiscriminately to control many pests worldwide. Many of these pesticides tend to have residual effect and may pose serious threat to the health of the consumers (El-Juhany $e t$ al., 2010).

Studies have abounded on the widespread use of pesticides in dates in Saudi Arabia especially in Dammam where about 16,000 date-palm farms are found in Ahsa, Eastern Province and many farms are using highly toxic pesticides. About 27 types of pesticides under 50 trade names were being used to fight the red date palm weevil in the previous region. At least 24 chemical components used in these pesticides are classified from medium to highly toxic, harmful to both the public health and the environment. With regard to the public health hazard, an increase in the cases of some diseases due to foods containing pesticides and displaying for sale at different markets.

\section{Pesticides}

'Pesticide' is substances that are used to kill or control plant pests, insects, weeds, fungi and other pathogens that cause damage to plants but they are the main reason for the most health problems in humans (Ortiz-Hernandez and Sanchez-Salinas, 2010). Pesticides play an important role in agriculturally dependant countries like India, Egypt and other developing countries (Agarry, 2013). Although they improve the plant quality and yield of the agricultural products, they have a certain serious effects on the environment. Millions of tons of pesticides are applied annually in modern agriculture (Mulchandani et al., 1999, Liu and Xiong, 2001) but less than $5 \%$ of these products are estimated to reach the target organisms.

\subsection{Effect of pesticides on the human health and environment}

Pesticides affect the human health which has been linked to a wide range of human health hazards, ranging from short-term impacts such as headaches and nausea to chronic impacts like cancer, reproductive harm, and endocrine disruption. Acute dangers such as nerve, skin, and eye irritation and damage, fatigue, and systemic poisoning can sometimes be dramatic and even occasionally fatal also. Pesticides affect children and there is now considerable scientific evidence that the human brain is not fully formed until the age of 12 years and childhood exposure to some of the most common pesticides on the market may greatly impact the development of the central nervous system. Moreover, children have more skin surface than adults, thus they absorb greater amounts of these substances through their lungs and intestinal tracts. Long term low dose exposure to pesticide causes immune suppression, hormonal disruption, diminished intelligence, reproductive abnormalities and carcinema (Gupta, 2004, Nawaz et al., 2011).The impacts of pesticides on the environment have been well known where they are toxic to living organisms and they can accumulate in water systems, 
pollute the air, and in some cases they have other dramatic environmental effects. The use of pesticide can damage agricultural land by harming beneficial insects, soil microorganisms, and worms, which naturally limit pest populations, necessary for soil health in addition they weakened plant root systems and immune systems and reduced concentrations of essential plant nutrients in soil such as nitrogen and phosphorous. The major environmental concern of used pesticides is their capacity to leach down to subsoil and contaminate the ground water (Kookana et al., 1998) or if immobile, they would persist on the top soil where it could accumulate to toxic level in the soil and become harmful to microorganisms, plants, animals and man (Amakiri, 1982, Surekha et al., 2008). The quality of soils, ground water, and coastal waters as well as the air are factors that affect pesticide contamination and degradation. Although pesticides are harmful, they are still used to fight the palm weevil.

\subsection{Types of pesticides according to the type of the pests they controlled}

Different types of pesticides are used on farms and they are grouped according to their use" or pests they kill e.g. herbicides that kill weeds, insecticides that kill insects, fungicides that kill fungi and rodenticides that kill rats, mice and other rodents.

\subsection{Types of pesticides according to their formula}

Many different formulas of pesticides are used to treat pests. Emulsifiable concentrate are fine suspensions of oil droplets in water and appears milky in color while wettable powders are suspensions of fine particles suspended in water. Moreover, granules are obtained by mixing the active ingredient with clay for outdoor application while baits are obtained by mixing the active ingredient with food base especially used for the control of rodents. Finally, dusts are applied dry with carriers like clay, talc, silica gel or diatomacious earth while fumigants are gaseous insecticides usually packaged under pressure and stored as liquids or pellets that release gas when mixed with water (Zacharia, 2011).

\subsection{Types of pesticides according to their major routes or modes of entry}

Pesticides can be absorbed into the body by three routes, through the skin (dermal absorption), through the lungs (inhalation), and by mouth through the stomach and intestines (ingestion). In typical work situations, skin absorption is the major route of entry of pesticides into the body. Moreover, contact pesticides must come into physical contact with the pest to be effective or may kill only the plant parts to which they are applied. Systemic pesticides are applied to either plants or soil to move throughout plants by the foliage or the roots and move throughout the target plant. Systemic insecticides are applied to soil, move through the host plant, and when the target insect after chewing or sucking the plant, it will be controlled (Ellsworth and Jones, 2001).

\subsection{Types of pesticides according to their origins \\ 2.5.1- Biopesticides:}

Biopesticides are certain types of pesticides derived from such natural materials as animals, plants, bacteria, and certain minerals. For example, canola oil and baking soda have pesticidal applications and are considered biopesticides. The main advantage of biopesticides is their safety to non-target organism, biodegradability and their specificity, which permits the use of small dosages and power exposure, hence avoiding pollution caused by conventional pesticides (Rosell et al., 2008). They are classified into three groups (Joshi, 2006). The fist is microbial pesticides are a microbial living organisms that used as the active control agents due to competition, antagonism and parasitism of microorganisms against plant pathogens, insects and weeds (Montesinos, 2003). Bacillus thuringiensis produced a crystalline inclusion body during sporulation (Frankenhuyzen, 2009). Fungi, viruses and Protozoa can act as important natural control agents against insects, pathogenic fungi, nematodes and weeds (Srivastava et al., 2009, Theilmann et al., 2005, Moscardi, 1999, Lacey and Goettel, 1995, Rosell et al., 2008). The second are plant-incorporated-protectants which were substances produced by plants from introducing genetic material that has been added to the plant. For example, the gene of Bacillus thuringiensis pesticidal protein was introduced into the plant's own genetic material. Then the plant, instead of the Bacillus thuringiensis bacterium, manufactures the substance that destroys the pest. The third were biochemical pesticides which are naturally occurring substances that include substances, such as insect sex pheromones that interfere with mating as well as various scented plant extracts that attract insect pests to traps.

\subsubsection{Chemical Pesticides:}

The most used chemical pesticides are belonging to organophosphates (Chlorpyrifos, Diazinon and Malathion), Carbamates and Organochlorines. Persistence of pesticides in soil for longer period is undesirable because accumulation of the chemicals in soil to highly toxic levels may be assimilated by the plants and get accumulated in edible plant products, specially the root parts. The effective persistence of pesticides in soil varies from a week to several years depending upon structure and properties of the constituents in the pesticide 
and availability of moisture in soil. For instance, the highly toxic phosphates do not persist for more than three months while chlorinated hydrocarbon insecticides (eg. DOT, aldrin, chlordane) are known to persist at least for 4-5 years and some times more than 15 years. Intensive use of DDT to control pests and mercurial fungicides to control plant diseases is very dangerous to human health due to accumulated in the food parts which lead to health hazards.

\subsubsection{Organophosphate pesticides:}

Pesticides of different chemical structures are toxic and persistence in the environment is not recommended. Currently, among the various groups of pesticides that are used worldwide, organophosphorus pesticides form the major and most widely used group that accounts for more than $36 \%$ of the total world market and their accumulation has many health hazards thus; its degradation is very important (Ghosh et al., 2010). Currently, organophosphates (OP) have high toxicity toward insects, mammals and other animals (Theriot and Grunden, 2011) and they are warfare nerve agents because they bind to acetylcholine esterase, a key enzyme of the central nervous system (Singh and Walker, 2006) and other cholinesterases leading to disruption of nerve impulses and killing the insect or interfering with its ability to carry on normal functions (Bakry et al., 2006). Their mechanism of action involves the irreversible inhibition of acetyl cholin esterase These compounds have a basic structure that consists of ester or thiol derivatives of phosphoric, phosphonic or phosphoramidic acids and include aliphatic, phenyl and heterocyclic derivatives (Kenneth, 1990, Vilanova and Sorgob, 1999, Ortiz-Hernández and Sánchez-Salinas, 2010). They included Diazinon, acephate, azinphosmethyl, bensulide, chlorethoxyfos, chlorpyrifos, dicrotophos, dimethoate, disulfoton, monocrotophos and malathion (Phugare, 2011) and are used to control a variety of sucking, chewing and boring insects, spider mites, aphids, and pests that attack crops like cotton, sugarcane, peanuts, tobacco, vegetables, fruits and ornamentals. OP pesticides are marketed by many of the world's major agrochemical companies.

Like all pesticides, intensive use of OP pesticides can lead to their accumulation in the environment and may affect ecosystems and human health. To mitigate the problem of contamination of OPs, treatments have been developed to detoxify and/or degrade these pesticides through physical, chemical and/or biological processes. In biological processes, biological systems (whole cells or isolated enzymes) are used to catalyze chemical reactions that transform the pesticide into simpler and less toxic compounds or, better yet, mineralize them into small non toxic molecules (Moreno-Medina et al., 2013). OP pesticides are all esters of phosphoric acid and owing to large-scale use, contaminations of soil and water systems have been reported from all parts of the world. Most OP compounds are degraded by microorganisms in the environment as a source of phosphorus and /or carbon. The OP pesticides can be hydrolyzed and detoxified by carboxylesterase and phosphotriesterase enzymes.

In man, the organophosphates are absorbed through all routes, reaching high concentrations in fatty tissues, liver, kidneys, salivary glands, thyroid, pancreas, lungs, stomach, intestines and, at smaller proportions, in the central nervous system and muscles. However, the organophosphates do not accumulate in the human organism, as it is readily biotransformed in the liver. The excretion of these compounds and their metabolites is quite fast, taking place mostly in the urine and, at small proportions, in the feces, usually within $48 \mathrm{~h}$. The largest excretion levels occur within $24 \mathrm{~h}$ after absorption (Oga, 2003, Griza et al., 2008). Due to the above mentioned health hazards and other problems associated with the use organophosphorus pesticides, early detection and subsequent decontamination and detoxification of the polluted environment is essential (Karpouzas and Singh, 2006, Porto, 2011).

\subsection{The organophosphate, Diazinon:}

The non-systemic insecticide Diazinon, O,O-Diethyl O-(2-isopropyl-4-methyl-6-pyrimidinyl) phosphorothioate, a colorless to dark brown organophosphate liquid insecticide and, developed in 1952 by Ciba-Geigy, a Swiss chemical company (Mallick et al., 1999). Diazinon is the fifth most commonly used pesticide, used by homeowners to control cockroaches, poultry, ant, silverfish and fleas in residential and non food buildings (Khani and Kafilzadeh, 2015). It can be used as foliage spray to control agricultural pests and can also be used as plant growth regulator (Mateen et al., 1994). The degradation of these chemicals differs with different soil types, physicochemical properties; their fertility and activities of microorganisms. Diazinon has an average half life of 30 days when applied to soil (Kennenth, 1990). Diazinon, a non systemic and is the drug of choice to control pests and insects but it is very harmful to beneficial insects, toxic to mammals when absorbed through the skin and is highly toxic to freshwater fish. Commercial Diazinon was roughly $90 \%$ pure with a boiling point around $83^{\circ} \mathrm{C}$, low water solubility of $40 \mathrm{ppm}$ at $20^{\circ} \mathrm{C}$. In soil Diazinon is a cholinesterase inhibitor and the symptoms of exposure depend on the dosage, duration of exposure, and route of exposure. 


\subsection{Biodegradation of pesticides}

Biodegradation is "Breakdown of a substance catalyzed by enzymes in vitro or in vivo. Microbial degradation of chemical compounds in the environment is an important route for the removal of these compounds. The biodegradation of pesticides is often complex processes and involves a series of biochemical reactions. Although many enzymes efficiently catalyze the biodegradation of pesticides, the full understanding of the biodegradation pathway often requires new investigations (Porto, 2011). A significant influence on biodegradation of pesticide could be the concentration at which they are present in contaminated soils. There is evidence that pesticide biodegradation rates in soil follow first-order kinetics and are concentration dependent. Pesticide may affect soil microbial populations, stimulating growth of certain microorganisms and exerting toxic effects and inhibiting growth of others. Diazinon is widely employed in agriculture and each year a lot of pesticides are entered into the environment through different ways (Khani and Kafilzadeh, 2014).

Microorganisms play a major role for saving our environments by degrading xenobiotic and chemicals wastes, which are toxic either in their native form or modified to be toxic. Isolation of microbial strains able to degrade chemical compounds was started usually from polluted sources, such as soil. Not all pesticides reaching to the soil are biodegradable and some chemicals that show complete resistance to biodegradation are called "recalcitrant". Biodegradation of pesticides is greatly influenced by the soil factors like moisture, temperature, $\mathrm{pH}$ and organic matter content, in addition to microbial population and pesticide solubility (Gunther, 1974). Most of the organic pesticides degrade within a short period (3-6 months) under tropical conditions. Metabolic activities of bacteria, fungi and actinomycetes have the significant role in the degradation of pesticides. Biodegradation of pesticides can be through detoxification which is conversion of the pesticide molecule to a non-toxic compound.

Degradation is breaking down of a complex substrate into simpler products leading finally to mineralization. Conjugation is complex formation to inactivate the pesticides. Activation is the conversion of non-toxic substrate into a toxic molecule, for eg. The herbicide, 4-butyric acid and the insecticide Phorate are transformed by soil microbes to give metabolites, toxic to weeds and insects. Changing the spectrum of toxicity of a compound in the soil to control one particular organism can be metabolized to yield products that were inhibitory to other groups of organisms, e.g. the fungicide PCNB which is converted in soil to chlorinated benzoic acids that kill plants. According to Gales (1952) principal of microbial infallibility, for every naturally occurring organic compound there is a microbe enzyme system capable of its degradation. Thus, microbes may have a major effect on the persistence of most pesticides in soil (Surekha et al., 2008) and biodegradation is a common method for the removal (breakdown and detoxification) of organic pesticides because of its low cost and low collateral destruction of indigenous animal and plant organisms (Liu et al., 2007).

\subsubsection{Fungal degradation of a pesticide:}

Extensive applications of persistent organochlorine pesticides like endosulfan on cotton have led to the contamination of soil and water environments at several sites and microbial degradation using several strains of bacteria and fungi offers an effective approach to remove such toxicants from the environment (Reddya, 2012). Development of a method to reduce the environmental burden of the pesticide by way of biodegradation must be carried out. Fungi like Aspergillus niger, Ganoderma austral, Trichosporon, Verticillium dahaliae showed significant ability to carry out the degradation of some pesticides like Malathion, Endosulfan (Hussaini, 2013).

\subsubsection{Bacterial degradation of a pesticide:}

OP compounds do not adversely affect bacteria, because bacteria do not possess acetylcholine esterase, and some microorganisms can even use OPs as an energy source (Singh, et al., 2006). The enzymes phosphotriesterases are found in microorganisms, animals and plants and can degrade OP compounds. In 1973, the first bacterium to degrade OP compounds was isolated from a soil sample from the Philippines and was identified as Flavobacterium sp. ATCC 27551 (Sethunathan and Yoshida, 1973), since then, several bacteria, a few fungi and cyanobacteria, have been isolated that can use OP compounds as a source of carbon, nitrogen or phosphorus. Enhancing biodegradation of OP compounds is also influenced by soil properties but with different efficiencies (Singh et al., 2006). A few consortia with the capability to metabolize OP compounds have also been reported for biotechnological applications (Singh et al., 2003, 2006).

Previously isolated bacterial strains for chlorpyrifos and fenamiphos degradation were used to examine their potential as bioremedial agents in soils and water containing pesticide residues. Degradation rate was slower in soil with lower $\mathrm{pH}$ in comparison with natural and alkaline soils, soil organic matter had no impact on pesticide degrading ability of the isolates while soil moisture slowed down degradation rate. The bacterial isolates were able to rapidly degrade fenamiphos and chlorpyrifos at $15-35^{\circ} \mathrm{C}$ but their degradation ability was sharply reduced at 5 and $50^{\circ} \mathrm{C}$ (Singh, 2006). Five bacteria isolated from coffee beans, identified as Pseudomonas aeruginosa, P. putida, Stenotrophomonas maltophilia, Flavimonas oryzihabitans and Morganella morganii. $P$. aeruginosa and $F$. oryzihabitans were selected for pesticide degradation according to their ability 
to grow on mineral medium amended with ground coffee beans and $50 \mathrm{mg} / \mathrm{l}$ of 1,1,1-trichloro-2, 2-bis (4chlorophenyl) ethane (DDT) or endosulfan and the greatest DDT removal was obtained in the medium supplemented with coffee beans (Barraga n-Huerta, 2007).

Many microorganisms can survive in pollutant environment due to the potential to degrade substance that harmful to our environment like chemical fertilizers and pesticides. Soil samples had been taken from dragon fruit plantation. Isolation of these microorganisms from soil with a history in using of pesticide was carried out and the genera Neisseria, Veillonella, Micrococcus and Staphylococcus were recorded for bioremediation technique in degrading pesticide (Ismail, 2008). A bacterial consortium which degrades tetrachlorvinphos (phosphoric acid, 2-chloro-1-(2,4,5-trichlorophenyl) ethenyl dimethyl ester) was isolated from agricultural soil. This consortium was composed of six pure strains, Stenotrophomonas malthophilia, Proteus vulgaris, Vibrio metschinkouii, Serratia ficaria, Serratia spp. and Yersinia enterocolitica (Ortiz-Hernandez, 2009). The bacterial mono-culture, RCC-2 was found to be most efficient with $21,37,54$ and $77 \%$ of chlorpyrifos degradation in 5, 10, 15 and 30 days of treatment duration, respectively while the two bacterial mixed-cultures was more effective with $24,38,56$ and $85 \%$ degradation in 5, 10, 15 and 30 days of treatment, respectively. Chlorpyrifos degradation was higher by increasing the culture volume of respective bacterial cultures, from $10 \%$ to $25 \%(\mathrm{v} / \mathrm{v})$, for 10 days of treatment at room temperature. The Pearson correlation between treatment duration and \% degradation of chlorpyrifos was 0.953 and 0.988 with bacterial mono- and mixed-cultures, respectively (Kumar, 2011).

In order to overcome the problem of commonly found pesticides namely Endosulfan, Chlorpyrifos and Cypermethrin, an enrichment culture technique was used to isolate bacterial strains from garden soil tolerating high concentrations of the selected pesticides. Five pure bacterial cultures were isolated which were able to grow in medium containing the individual pesticide as the carbon source. There is positive correlation between pesticide degradation and tolerance to metals and antibiotics (Naphade, 2012). To study the endosulfan degrading microorganisms, 20 soil samples were collected from five different cashew plantations with a history of Endosulfan applications. The bacterial strains were isolated using enrichment technique and different concentrations of endosulfan. The bacterial strain showed maximum growth at $100 \mu \mathrm{l} / 100 \mathrm{ml}$ of distilled water and there was no residual Endosulfan in the soil, therefore complete mineralization has occurred leading to non toxic low molecular weight compounds by Pseudomonas sp. 2C and Alcaligenes sp. XDC22 (Sarat, 2013).

A bacterial consortium of Proteus vulgaris, Vibrio sp., Serratia sp. and Acinetobacter sp.which degraded Dichlorvos pesticide was isolated from agricultural soil using pour plate method (Agarry, 2013). Malathion biodegradation in liquid medium with five bacterial strains from agricultural soil, Bacillus amyloliquefaciens, Staphylococcus sciuri, Pseudomonas earuginosa, Bacillus pseudomycoides and Bacillus licheniformis was increased compared to control treatment (Tamer and Thabit, 2013). The persistence of Monocrotophos, an extensively used Organophosphorous pesticide in environment and its toxic effect on biota, necessitate its removal. In medium, two fungal isolate and one bacterial isolate were found to show tolerance against $1 \%$ Monocrotophos and these microorganisms showed bioremediation activity in the environment (Baghel, 2013).

Eighty-two bacterial isolates with potential Carbofuran degradation activity were obtained from soils cultivated with the potato (Solanum tuberosum) in Colombia with different records of pesticide application. The bacteria were selected for their ability to grow in medium containing $200 \mathrm{mg} / \mathrm{l}$ Carbofuran as the sole source of carbon and/or nitrogen. Sphingomonas paucimobilis, Pseudomonas aeruginosa and Yersinia pseudotuberculosis had the ability of hydrolytic degradation of Carbofuran (Rozo, 2013).

In the presence of Carbosulfan pesticide, Pseudomonas was isolated from Solanum melongena (brinjal) cultivated soil, having a history of pesticide usage in Khulna region, Bangladeh and this isolate was valuable for bioremediation of pesticide contaminated soils (Sharif, 2013).

Chlorophenols (CP) are quite persistent in the environment causing serious pollution problems to surface and subsurface environments and biodegradation of $\mathrm{CP}$ by the bacterial consortium was in 50 days and the germination study showed that treatment of seeds by microbial consortium resulted in $100 \%$ germination indicating the efficiency of the treatment (Logakanthi, 2013). The effect of pesticide (Chlorpyrifos) on rhizospheric soil and non-rhizospheric soil of two plants marigold and Canna has been investigated and the efficiency of microbial consortium on Forchlorpyrifos degradation has been studied. The presence of glucose supports more biomass for higher degradation and dissipation of pesticide. Rhizoremediation is the most evolved process of bioremediation which involve the remediation of contaminants by interaction of microflora associated with plant roots in mycorrhizosphere. Pennisetum pedicellatum and Cenchrus setigerus have been selected for rhizosphere remediation of selected pesticides Chlorpyrifos, Cypermethrin and Fenvalerate. A consortium survived in pesticides environment which was identified as Stenotrophomonas maltophila, and Sphingobacterium thalpophilum (Fulekar, 2014). Using enrichment culture technique and minimal salt growth medium where Diazinon served as a sole carbon source, Pseudomonas peli, Burkholderia caryophylli and Brevundimonas diminuta were able to completely degrade $20 \mathrm{mg} / \mathrm{l}$ Diazinon within 12 days of incubation. The bacterial growth and Diazinon degradation were accelerated by these isolates when the medium was 
supplemented with $0.5 \%(\mathrm{w} / \mathrm{v})$ glucose as an additional carbon source and there is a correlation among Diazinon degradation, microbial growth and medium $\mathrm{pH}$ (Mahiudddin, 2014). Complete biodegradation of a pesticide involves the oxidation of parent compound to form carbon dioxide and water. This process provides both carbon and energy for the growth and reproduction of microbes. Each degradation step is catalyzed by specific enzyme produced by a degrading cell or enzyme found external to the cell. Degradation of pesticide by either external or internal enzyme stops at any step if an appropriate enzyme is not present. Absence of an appropriate enzyme is one of the common reasons for persistence of any pesticide. If an appropriate microorganism is absent in soil or if biodegrading microbial population has been reduced due to toxicity of pesticide in that case a specific microorganism can be added or introduced in soil to enhance the activity of the existing population (Singh, 2008). The use of bacteria for the degradation and detoxification of numerous toxic chemicals such as pesticides is an effective tool to decontaminate the polluted sites. Isolation of indigenous bacteria capable of metabolizing pesticides provides environmentally friendly means of in situ detoxification (Mervat, 2009). Degradation by microbes depends not only on the presence of enzymes, but also on a wide range of environmental parameters. Temperature, $\mathrm{pH}$, water potential, nutrients and the amount of pesticide or metabolite in soil may also act as limiting factor for pesticide degrading microorganisms, which requires further exploration in relation to total microbial population and their biochemical activities (Singh, 2008).

\subsubsection{Pesticide biodegradation using a consortium}

Methyl parathion (MP) degradation using one bacterial was not detected but an active consortium that would degrade MP was isolated from the organic solid waste (Botero, 2012). Bacterial consortium from agricultural soils can be used to degrade a mixture of the organophosphate pesticides, methyl parathion and coumaphos in mineral salt medium supplemented with glucose, and the immobilized bacterial consortium on Luffa fibers removed 98 and $100 \%$ of those pesticides (Moreno-Medina, 2013). The constant application of pesticides has led to environmental and health problems in many regions of the world. For this reason, it is necessary to develop strategies for the disposal of pesticides that are ecofriendly and economically viable and used bioremediation methods for cleaning soil and waters. Different treatment options exist, but in recent years, the application of biological systems has gained the greatest acceptance, because it promises the degradation and detoxification of pesticides without harming the environment or human health.

\subsection{Microbial enzyme systems in pesticide biodegradation}

Organophosphorus pesticides are widely used throughout the world and its residues are regularly detected in a range of fruits and vegetables. Investigation of microbial degradation is useful for developing insecticide degradation strategies using microorganisms. The enzymes play a key role in the biodegradation of any xenobiotic compounds. The enzymes involved in such OP degradation mechanisms were purified from the different microbial source. There are three different types of well-characterized bacterial Phosphotriesterases. Organophosphorus hydrolase and organophosphorus acid anhydrolase are the key enzymes amongst them (Phugare and Swapnil Suresh, 2011).

\subsubsection{Organophosphorus hydrolases}

Organophosphorus hydrolases were purified from B. diminuta and Flavobacterium spp. and have identical, or very similar, amino-acid sequences (Mulbry and Karns,1989, Siddavattam et al., 2003, Serdar et al., 1982). A variant of OPH called OPDA (OP-degrading enzyme) has been purified from A. radiobacter(Phugare, 2011, Horne et al., 2002, Singh, 2009).

\subsubsection{Organophosphorus acid anhydrolase}

Another OP-degrading enzyme that has received considerable attention is OPAA (organophosphorus acid anhydrolase), which was isolated from Alteromonas undina and Alteromonas haloplanktis (Chen et al., 1993, Chen et al., 1999). This enzyme belongs to the dipeptidase family and does not share enzyme or gene-sequence similarity with $\mathrm{OPH}$.

\subsubsection{Arlyaclyamidase:}

Arlyaclyamidase from Bacillus sphaericus was purified and the molecular weight of the enzyme was near about $75 \mathrm{kDa}$ (Phugare, 2011).

\subsection{Removal of pesticides by an immobilized bacterial consortium:}

Biological methods are gaining interest due to their simplicity, high efficiency and cost effectiveness compared to other methods (Chandran and Das, 2011). Biodegradation of pesticides provides a cheap and efficient solution for their final disposal or for the treatment of agricultural soils, contaminated water or polluted ecosystems. To date, a number of different microorganisms have been identified, and the enzymes involved in 
OP degradation have been studied (Singh, 2009, Ortiz-Hernández et al., 2011). In order to optimize biological treatment, different strategies have been developed. Among them, cell immobilization has been a successful approach that ensures that the catalytic activity of the biological processes is maintained for longer periods (Manohar et al., 2001, Cheng et al., 2003, Yáñez-Ocampo et al., 2009). Immobilization consists in restricting cell mobility within a defined space of a material with particular characteristics. There are two types of processes for cell immobilization: those based on physical retention (entrapment and inclusion membrane) and those based on chemical bonds, such as biofilm formation (Kennedy and Cabral, 1983). In cell immobilization methods, various inorganic (clays, silicates, glass and ceramics) and organic (cellulose, starch, dextran, agarose, alginate, chitin, collagen, keratin, etc.) supports are employed (Hyde et al., 1991).

The most widely studied method for the practical application of immobilized cell techniques is entrapping cells in polymer gels, such as alginate and carrageenan. However, this method has been limited by problems with gel stability and by the mass transfer limitations of gel beads. Entrapment in natural polymeric gels has become the preferred technique for the immobilization of cells, due to the toxicity problems associated with the synthesis of polymeric materials (Lusta et al., 1990).

\section{References}

[1]. Adawiyah, I. (2008). Isolation, characterization and identification of microorganism from soil contaminated with pesticide (Doctoral dissertation, University of Malaysia, Pahang.

[2]. Agarry, S.E., Olu-Arotiowa, O.A., Aremu, M.O. and Jimoda, L.A. (2013). Biodegradation of Dichlorovos (Organophosphate Pesticide) in soil by bacterial isolates. Biodegradation, 3(8): 11-16.

[3]. Amakiri, M.A. (1982). Microbial degradation of soil applied herbicides. Nig. J. Microbiol., 2: 17-21.

[4]. Baghel, P. S. and Pandey,B. (2013). Isolation of microorganism for mioremediation of monocrotophos pesticide. Int. J. Curr. Microbiol. App. Sci., 2(11): 202-205.

[5]. Bakry, N., El-Rashidy, A., Eldefrawi, A. and Eldefrawi, M. (2006). Direct actions of organophosphate anticholin esterases on nicotinic and muscarinic acetylcholinic receptors. J. Biochem. Toxicol., 3(4): 235-259.

[6]. Barragan-Huerta, B.E., Costa-Perez, C., Peralta-Cruz, J., Barrera-Cortes, J., Esparza-Garcia, F. and Rodriguez-Vazquez, R. (2007). Biodegradation of organochlorine pesticides by bacteria grown in microniches of the porous structure of green bean coffee. Int. Biodet. Biodeg., 59: 239-244.

[7]. Botero-Coy, A.M., Marin, J.M., Ibanez, M., Sancho, J.V., Hernandez, F. (2012). Multi-residue determination of pesticides in tropical fruits using liquid chromatography/tandem mass spectrometry. Anal. Bioanal. Chem., 402:2287-2300.

[8]. Chandran, P. and Das, N. (2011). Degradation of diesel oil by immobilized Candida tropicalis and biofilm formed on gravels. Biodegradation, 22(6), 1181-1189.

[9]. Chen, J., Cui, Y. and Deakyne, R.O. (1993). Residue analytical method for RH-5592 in cabbage, lettuce, mustard green, spinach, broccoli and celery. Rohm and Haas report NO. 34-93-119.

[10]. Chen, K.C., Huang, W.T., Wu, J.Y., Houng, J.Y. (1999). Microbial decolorization of azo dyes by Proteus mirabilis. Journal of Industrial Microbiology and Biotechnology, 23:686-690.

[11]. Cheng, K., Wu, J., Yang, W., Hwang, S. (2003). Evaluation of effective diffusion coefficient and intrinsic kinetic parameters on azo dye biodegradation using PVA-im-mobilized cell beads. Biotechnol. Bioeng. 83, 821-832.

[12]. El-Juhany, L. I (2010). Degradation of Date Palm Trees and Date Production in Arab Countries: Causes and Potential Rehabilitation. Australian Journal of Basic and Applied Sciences, 4(8): 3998-4010.

[13]. Ellsworth, P.C. and Jones, J.S. (2001). Cotton IPM in Arizona: A Decade of Research, Implemention and Education. Cotton: A College of Agriculture Report.

[14]. Frankenhuyzen, K.V. (2009). Insecticidal activity of Bacillus thuringiensis crystal proteins. Journal of Invertebrate Pathology, Vol.101(1): pp. 1-16.

[15]. Fulekar, M.H. (2014). Rhizosphere bioremediation of pesticides by microbial consortium and potential microorganism. International Journal of Current Microbiology and Applied Science,Vol. 3 (7): pp. 235-248.

[16]. Gale, E.F. (1952). The chemical activities of bacteria. New York, Academic Press. Pages 234.

[17]. Ghosh, P.G., Sawant, N.A, Patil, S.N., Aglave, B.A. (2010). Microbial biodegradation of organophosphate pesticides. International Journal of Biotechnology and Biochemistry, Vol. 6 (6), pp. 871-876.

[18]. Griza, F. T., Ortiz, K. S., Geremias, D., \&Thiesen, F.V. (2008). Evaluation of the organophosphates pesticides contamination in superficial water of Rondinha-Rio Grande do Sul. Química Nova, 31(7), 1631-1635.

[19]. Gunther, A.F. (1974). Residues of pesticides and other contaminants in the total environment. Residue Reviews, Springer-Verlag

[20]. Gupta, P.K. (2004). Pesticide Exposure-Indian Scene. Toxicol., 198: 83-90.

[21]. Ha, J. (2005). Bioremediation of the organophosphate pesticide, coumaphos, using microorganisms immobilized in calciumalginate gel beads. Thesis, Texas University. $181 \mathrm{pp}$.

[22]. Horne, I., Sutherland, T.D., Harcourt, R.L., Russell, R.J. and Oakeshott, J.G. (2002) Identification of an opd (organophosphate degradation) gene in an Agrobacterium isolate. Appl. Environ. Microbiol.,68, 3371-3376.

[23]. Hussaini, S.Z., Shaker, M., Iqbal, M. (2013). Isolation Of Fungal Isolates For Degradation Of Selected Pesticides. Bull. Env. Pharmacol. Life Sci., Vol. 2 (4) March 2013: 50-53.

[24]. Hyde, F.W, Hunt, G.R. and Errede, L.A. (1991). Immobilization of bacteria and Saccharomyces cerevisiae in poly(tetrafluoroethylene) membranes. Appl. Environ. Microbiol., 57(1): 219-222.

[25]. Joshi, S.R. (2006). Biopesticides: a biotechnological approach. New Age International

[26]. Karpouzas, D.G. and Singh, B.K. (2006). "Microbial degradation of organophosphorus xenobiotics: Metabolic pathways and molecular basis," In : Advances in Microbial Physiology, K. P. Robert, Ed., Academic Press, pp. 119-225.

[27]. Kennedy, J.F. and Cabral, J.M.S. (1983). Immobilized enzymes. In Solid Phase. Biochemistry (W. I. Scouten, Ed), Wiley, New York, p. 245-293.

[28]. Kenneth, D.R., Dennis A.L., Mark, R.S. (1990). Resistance of chlorpyrifos to enhanced biodegradation in soil. J. Agric. Food Chem., 38 (6), pp 1430-1436.

[29]. Khani, M. and Kafilzadeh, F. (2015). Diazinon degradation by Pseudomonas earuginosa and Flavobacterium bacteria and assessing the growth Kinetics. Journal of Biology and Today's World, 4 (2): 44-48. 
[30]. Kookana, R.S, Baskaran, S., Naidu, R. (1998). Pesticide fate and behavior in Australian soils in relation to contamination and management of soil and water: a review. Aust. J. Soil Res., 36: 715-764.

[31]. Kumar, S. (2011) Bioremediation of chlorpyrifos by bacteria isolated from the cultivated soils vol 3 issue 3 pp 359-366.

[32]. Lacey, L.A. and Goettel, M.S. (1995). Current Developments in Microbial Control of Insect Pests and Prospects for the Early 21st Century. Entomophaga,vol.40, pp.3-27.

[33]. Liu, F., Hong, M., Liu D. and Li, Y. (2007). Biodegradation of methyl parathion by Acinetobacter radioresistens USTB-04. J. Environ. Sci., 19(10): 1257-1260.

[34]. Liu, Y.Y. and Xiong, Y. (2001). Purification and characterization of adimethoate-degrading enzyme of Aspergillus niger ZHY256 isolated from sewage. Appl. Environ. Microbiol., 67: 3746-3749.

[35]. Logakanthi, S., Arulazhagan, P. and Vasudevan, N. (2013). Degradation of Pentachlorophenol by a bacterial consortia and the effect of cured soil on Phaseolus mungo L. International Journal of Current Microbiology and Applied Sciences, 6(2)11-23.

[36]. Lusta, K.A., Starostina N.G. and Fikhte, B.A. (1990). Immobilization of microorganisms: cytophysiological aspects. In: Proceedings of an International Symposium: Physiology of Immobilized Cells (J.A.M. De Bont, J. Visser, B. Mattiasson and J. Tramper Eds.). Elsevier, Amsterdam, the Netherlands, pp. 557-562.

[37]. Mahiudddin, M., Fakhruddin, A. N. M., Abdullah-Al-Mahin, Chowdhury, M. A. Z., Rahman, M. A., Alam, M. K. (2014). Degradation of the organophosphorus insecticide Diazinon by soil bacterial isolate. J. Biotechnology, 3(1): 12-23.

[38]. Mallick, K., Bharati, K., Banerji, A., Shakil, N.A., Sethunathan, N. (1999). Bacterial degradation of chlorpyrifos in pure cultures and in soil. Bulletin of environmental contamination and toxicology, 62(1):48-54.

[39]. Manohar, S., Kim, C.K. and Karegoudar, T.B. (2001). Enhanced degradation of naphthalene by immobilization of Pseudomonas sp Strain NGK1 in polyurethane foam. Appl. Microbiol. Biotechnol. 55, 311-316.

[40]. Mateen, A., Chapalamadugu, S., Kaskar, B., Bhatti, A.R. and Chaudhry, G.R. (1994). Microbial metabolism of carbamate and organophosphate pesticides In: Biological degradation and bioremediation of toxic chemicals. Chaudry G S. (ed). Chapman and Hall London, 198 - 233.

[41]. Mervat, S.M. (2009). Degradation of methomyl by the novelbacterial strain Stenotrophomonas maltophilia M1. Elect. J. Biotech., 12(4): $1-6$.

[42]. Montesinos, E. (2003). Development, Registration and Commercialization of Microbial Pesticides for Plant Protection.International Microbiology, Vol. 6, No. 4, pp. 245-252.

[43]. Moreno-Medina, D.A., Sanchez- Salinas, E., and Ortiz-Hernandez, M.L. (2013). Removal of methyl parathion and coumaphos pesticides by a bacterial consortium immobilized in luffa cylindrical. Rev. Int. Contam. Ambie, 30, 51-63.

[44]. Moscardi, F. (1999). Assessment of the application of baculoviruses for control of Lepidoptera. Annual Review of Entomology, Vol. 44, pp: 257-289.

[45]. Mulbry, W.W. and Karns, J.S. (1989). Parathion hydrolase specified by the Flavobacterium opd gene: relationship between the gene and protein. Journal of Bacteriology, 171(12), 6740-6746.

[46]. Mulchandani, A., Kaneva, I. and Chen, W. (1999). Detoxification of organophosphate pesticides by immobilized Escherichia coli expressing organophosphorus hydrolase on cell surface. Biotechnol. Bioeng., 63, 216-223.

[47]. Naphade, S.R., Durve, A.A., Bhot, M., Varghese, J. and Chandra N. (2012). Isolation, characterization and identification of pesticide tolerating bacteriafrom garden soil. European Journal of Experimental Biology, 2 (5):1943-1951.

[48]. Nawaz, K., Hussain, K., Choudary, N., Abdul Majeed1, Ilyas,U., AbdulGhani, Lin, F. , Ali, K., Shahid Afghan, S., Raza G. and Lashari M. I. (2011). Eco-friendly role of biodegradation against agricultural pesticides hazards. African Journal of Microbiology Research, Vol. 5(3):177-183.

[49]. Oga, S. et al.Praguicidas.(2003)In: OGA, S. Fundamentos de toxicologia. 2. ed. São Paulo: AtheneuEditora, 2003. p. 437-58.

[50]. Ortiz-Hernandez, M.L. and Sanchez-Salinas, E. (2009). Biodegradation of the organophosphate pesticide tetrachlorvinphos by bacteria isolated from agriculture soils in Mexico. Rev. Int. Contam. Ambient., 26(1): 27-38.

[51]. Ortiz-Hernández, Ma Laura, and Enrique Sánchez-Salinas. (2010). "Biodegradation of the organophosphate pesticide tetrachlorvinphos by bacteria isolated from agricultural soils in México." Rev. Int. Contam. Ambient, 26.1: 27-38.

[52]. Phugare, S.S. (2011). Microbial systems for bioremediation of toxicants. Shivaji University, http://shodhganga.inflibnet.ac.in/handle/10603/10023

[53]. Phugare, S.S. (2011). Microbial systems for bioremediation of toxicants. Shivaji University, India., 226p

[54]. Porto, A.L.M., Melgar, G.Z., Kasemodel, M.C. and Nitschke, M. (2011). Biodegradation of pesticides. Pesticides in the modern world, pesticides use and management. In Tech, 407-438.

[55]. Reddy, G.V.P., and Bautista, J.R. (2012). Integration of the predatory mite Neoseiulus californicus and petroleum spray oil for control of Tetranychusmarianae on eggplant. Biocontrol Science and Technology, 22,1211-1220.

[56]. Rosell,G., Quero, C., Coll, J. and Guerrero, A. (2008). Biorational insecticides in pest management. Journal of Pesticide Science, Vol. 33, No. 2, pp. 103-121.

[57]. Rozo C J., Sánchez Nieves, J., Uribe Vélez, D., Moreno Chacón, L., and Melgarejo Muñoz, L.M. (2013). Characterization of carbofuran degrading bacteria obtained from potato cultivated soils with different pesticide application records. Revista Facultad Nacional de Agronomía, Medellín, 66 (1), 6899-6908.

[58]. Sarat, N.S. and Barathi, S. (2013). Enrichment and isolation of Endosulfan degrading microorganisms in Cashew plantations of Kasargod District, Kerala. International Journal of Chem. Tech. Research, Vol.5 (1), pp. 06-14.

[59]. Serdar, C.M., Gibson, D.T., Munnecke, D.M. and Lancaster, J.H. (1982). Plasmid involvement in parathion hydrolysis by Pseudomonas diminuta. Appl. Environ. Microbiol., 44, 246-249.

[60]. Sethunathan, N. and Yoshida, T. (1973). Flavobacterium sp. that degrades diazinon and parathion. Can. J. Microbiol.,19: 873-875.

[61]. Sharif D. I. and Mollick M. (2013). Selective isolation of a gram negative carbamate pesticide degrading bacterium from brinjal cultivated soil. American Journal of Agricultural and Biological Sciences 8 (4): 249-256.

[62]. Siddavattam, D., Khajamohiddin, S., Manavathi, B., Pakala, S. B., \& Merrick, M. (2003). Transposon-like organization of the plasmid-borne organophosphate degradation (opd) gene cluster found in Flavobacterium sp. Applied and environmental microbiology, 69(5), 2533-2539.

[63]. Singh B K and Walker A. (2006). Microbial degradation of organophosphorus compounds. FEMS Microbiol.Rev.,30: 428-471 .

[64]. Singh, B. K. (2009). Organophosphorus-degrading bacteria: ecology and industrial applications. Nature Reviews Microbiology, 7(2), 156-164.

[65]. Singh, B. K., Walker, A., Morgan, J. A. W. and Wright, D. J.(2003). Effects of soil pH on the biodegradation of chlorpyrifos and isolation of a chlorpyrifos-degrading bacterium. Appl. Environ. Microbiol., 69, 5198-5206.

[66]. Singh, D.K. (2008). Biodegradation and bioremediation of pesticide in soil: concept, method and recent developments. Indian J. Microbiol., 48: 35-40. 
[67]. Srivastava, C. N.; Maurya, P.; Sharma, P. and Mohan, L. (2009). Prospective role of insecticides of fungal origin: Review.Entomological Research, Vol.39, No.6, pp. 341-355.

[68]. Surekha, R., Lakshmi, P., Suvarnalatha, D., Jaya, M., Aruna, S., Jyothi, K., Narasimha, G. and Venkateswarlu, K. (2008). Isolation and characterization of a chlorpyrifos degrading bacterium from agricultural soil and its growth response. Afr. J.Microbiol. Res., 2(1): 26-31.

[69]. Thabit, T. M., and El-Naggar, M. A. (2013). Malathion degradation by soil isolated bacteria and detection of degradation products by GC-MS. International Journal of Environmental Sciences, 3(5), 1467.

[70]. Theilmann, D. A., Blissard, G. W., Boning, B., Jehle, J. A., O'reilly, D. R., Rohrmann, G. F. and Vlak, J. M. (2005). Baculoviridae. In Virus Taxonomy, VIII th Report of the International Committee on Taxonomy of Viruses (pp. 177-185). Elsevier/Academic Press.

[71]. Theriot, C.M. and Grunden, A.M. (2011). Hydrolysis of organophosphorus compounds by microbial enzymes. Appl. Microbiol. Biotechnol. 89, 35-43.

[72]. Vilanova, E. and Sorgob, M.A. (1999). The role of phosphotriesterases in the detoxication of organophosphorus compounds. Crit. Rev. Toxicol., 29, 21-57.

[73]. Yañez-Ocampo, G., Sánchez-Salinas, E., Jiménez-Tobon, G. A., Penninckx, M. and Ortiz-Hernández, M.L. (2009). Removal of two organophosphate pesticides by a bacterial consortium immobilized in alginate or tezontle. J. Haz. Mat., 168, $1554-1561$.

[74]. Zacharia, J.T. (2011). Identity, physical and chemical properties of pesticides. Pesticides in the modern world-trends in pesticides analysis, (Margarita Stoytcheva, ed.), Publisher: InTech, Croatia. 